\title{
Genetic Diversity of Chilli (Capsicum annuum L.) Genotypes
}

\author{
Paramjeet Singh Negi* and Akhilesh Sharma \\ Department of Vegetable Science and Floriculture, CSK Himachal Pradesh Krishi \\ Vishvavidyalaya, Palampur, 176062, India
}

*Corresponding author

\begin{abstract}
A B S T R A C T
Keywords

Chilli, Genetic divergence,

Dendrogram,

Genetic mean

Article Info

Accepted:

15 March 2019

Available Online:

10 April 2019

The experimental material comprised of 27 advance breeding lines and six varieties including 'Surajmukhi' as standard in randomized complete block design with three replications during summer- rainy season 2017. Genetic diversity studies grouped 33 chilli genotypes into six clusters. Maximum genotypes were placed in cluster I (16 genotypes) followed by cluster II (7 genotypes). Highest intra-cluster distance was observed for cluster IV followed by cluster II while maximum inter-cluster distance was observed between cluster V and VI followed by IV and V. Cluster V was observed to be the most important with maximum cluster means for most of the valuable traits. Total red ripe fruits per plant contributed maximum towards total genetic divergence followed by oleoresin content and marketable red ripe fruits per plant. Based on genetic divergence studies, best performing genotypes from cluster V, I, II, VI and III offer promise for their direct use as varieties and as potential parents in future breeding programmes to isolate transgressive segregants.
\end{abstract}

\section{Introduction}

Chilli or hot pepper (Capsicum annuum var. annuum L.), belongs to the family Solanaceae and is one of the common and remunerative cash crops grown for its green and dry red fruits especially as spice in Indian subcontinent. The alkaloid capsaicin present in placenta of chiili fruit responsible for its pungency has diverse prophylactic and therapeutic uses in Allopathic and Ayurvedic medicine (Sumathy and Mathew, 1984). India has immense potential to grow and export different types of chillies required by various markets around the world. Indian chilli exports nowadays, is facing severe competition in the international market from other chilli growing countries along with high domestic. Chilli production has also suffered a lot due to non-availability of suitable cultivars, biotic and abiotic stresses and extensive cultivation of one or two specific which has resulted in plethora of disease infestation. Thus, there is a pressing demand to develop high yielding varieties or hybrids with good quality attributes to enhance the productivity.

$\mathrm{D}^{2}$ statistic is a potent tool for estimating genetic diversity among different genotypes and to identify the parents for hybridization to obtain desirable recombinants. Evaluation of 
genetic diversity is important to know the source of genes for a particular trait within the available germplasm (Tomooka, 1991). The assessment of genetic divergence helps in reducing the number of breeding lines from the large germplasm. Also, the progenies derived from diverse parents are expected to show a broad spectrum of genetic variability and provide better scope to isolate superior recombinants. Selection of genotypes from divergent clusters and components having more than one positive trait for hybridization programme may lead to improvement in yield (Singh et al., 2017).

\section{Materials and Methods}

The investigation was conducted at the Experimental Farm of Department of Vegetable Science and Floriculture, Chaudhary Sarwan Kumar Himachal Pradesh Krishi Vishvavidyalaya, Palampur (1,290.8 m above mean sea level with $3206^{\prime} \mathrm{N}$ latitude and $7603^{\prime} \mathrm{E}$ longitude) during summer- rainy season 2017. The soil is classified as Alfisolstypic Hapludalf clay having a $\mathrm{pH}$ of 5.7. The experimental material comprising of 33 genotypes was sown on $14^{\text {th }}$ March 2017 and the seedlings were ready for transplanting in about eight weeks after seed sowing. The experiment was laid out in randomized complete block design with three replications. Each genotype was planted in two rows of length $2.25 \mathrm{~m}$ consisting of ten plants in each replication with inter and intra row spacing of $45 \mathrm{~cm} \times 45 \mathrm{~cm}$, respectively. The observations were recorded on five competitive plants taken at random each for fresh and dry chilli separately in each entry over the replications for the traits namely, days to flowering, days to first harvest, pedicel length, fruit length, fruit girth, fruit width, leaf length, leaf width, plant height, primary branches/plant, secondary branches/plant, average green fruit weight, marketable green fruits/plant, marketable green fruit yield/plant, harvest duration, average red ripe fruit weight, marketable red ripe fruits/plant, non- marketable red ripe fruits/plant, total red ripe fruits/plant, per cent marketable red ripe fruits/plant, red ripe fruit yield/plant, average dry fruit weight, dry fruit yield/plant, ascorbic acid, oleoresin and capsaicin content. Using $\mathrm{D}^{2}$ values, different genotypes were grouped into various clusters following Tocher's method as suggested by Rao (1952).

\section{Results and Discussion}

Genetic diversity of germplasm determines their potential for improved efficiency and thereby utilizing diverse genetic material in breeding programme which may eventually result in enhanced crop production. Amongst the various tools to assess genetic diversity, $\mathrm{D}^{2}$ statistic is a powerful tool for estimating genetic diversity and to identify the parents for hybridization to obtain desirable recombinants since diverse parents lead to high heterosis (Khodadadi et al., 2011). Inclusion of diverse parents in hybridization program provides an opportunity to combine desirable genes and hence, resulted in isolation of superior lines with requisite traits (Ceolin et al., 2007). Cluster analysis is the most suitable approach in identifying variability in germplasm, lessen the number of breeding lines by eliminating duplicates from large germplasm and thereby, suggests appropriate parents to be involved in conventional breeding (Eivazi et al., 2007).

With Euclidean cluster analysis, 33 genotypes of chilli were grouped into six clusters (Fig. 1, Table 1). Among them, cluster I, II, IV, V and VI were polygenotypic whereas cluster III and VI were monogenotypic containing genotypes namely, DPCH-29-1 and DPCH28-1 respectively. Different clustering patterns in chilli were also reported by earlier workers viz., Bijalwan et al., (2018) and 
Janaki et al., (2015) in their respective studies. Cluster I comprised of maximum 16 genotypes viz., 'DPCH 38-2', 'DPCH 38-2-2', 'DPCH 38-1-1', 'DPCH 32-1-1', 'DPCH 57', 'Surajmukhi', 'DPCH 26-1-1', 'DPCH 14-1', ' $\mathrm{DPCH}$ 40', 'DPCH 27', 'DPCH 33-1', 'DPCH-31', '2016/-CHIVAR-6', 'DPCH21',' 2016/CHIVAR-5' and 'DPCH-13-1' followed by cluster II with seven genotypes viz., 'DPCH-35', 'DPCH 39-2', 'DPCH-10', 'DPCH-36', 'DPCH-17-2', 'DPCH-41' and '2016/ CHIVAR-1' and that of cluster IV with six ('2016/CHIVAR-4', 'DPCH 32-2', '2016/CHIVAR-3', 'DPCH 6-2', 'DPCH-22' and 'DPCH 12-1') and cluster $\mathrm{V}$ with two genotypes ('DPCH-9' and 'DPCH 32-2-1'). Different research workers namely, Dutonde et al., (2008), Dutta and Jana (2010) and Pujar et al., (2017) also found maximum genotypes in cluster-I.

The intra-cluster distance varies from 0 to 214.93 with the highest in cluster IV followed by 176.83 in cluster II, 153.35 in cluster I and 139.83 in cluster $\mathrm{V}$ while monogynotypic cluster had intra-cluster distance with zero value. The inter-cluster distance ranged from 242.78 to 3462.64 (Table 2). The highest inter-cluster genetic divergence was recorded between clusters V and VI followed by IV and V and III and V. This clearly indicates that the genotypes included in the clusters with high inter-cluster distance showed sufficient genetic diversity and selection of parents from these diverse clusters would be useful in hybridization programme for improving yield and other desirable horticultural traits. The crosses involving the diverse genotypes would be expected to manifest maximum heterosis and are more likely to evolve desirable recombinants in segregating generations. The minimum intercluster distance was observed between genotypes of cluster I and III which can be used for backcross breeding programmes. The genotypes of cluster I and II and that of III and IV also showed minimum inter-cluster distance. The low inter-cluster distance between these cluster pairs suggested close proximity of genotypes grouped in these clusters with respect to their genetic constitution. The genotypes grouped into the same cluster presumably diverge very little from one another and crossing of genotypes belonging to the same cluster is not expected to yield desirable segregants. Based on intercluster distance, the earlier workers namely, Mishra et al., (2001), Srinivas et al., (2013) and Janaki et al., (2015) have also suggested selection of parents from diverse clusters for utilization in hybridization programme to obtain desirable transgressive segregants.

The composition of cluster means of chilli genotypes for different characters showed considerable differences among the clusters for each trait (Table 3). Cluster $\mathrm{V}$ was observed to be the most important with maximum cluster means for most of the valuable traits namely, secondary branches/plant, marketable green fruits/plant, marketable green fruit yield/plant, marketable red ripe fruits/plant, total red ripe fruits/plant, red ripe fruit yield/plant and dry fruit yield/plant along with short harvest duration. In addition, it also showed desirable means for majority of the fruit and plant growth traits namely, pedicel length, fruit length, fruit girth, fruit width, plant height, average green/dry fruit weight, ascorbic acid and capsaicin content.

Similarly, Cluster III showed maximum means for fruit girth, fruit width, leaf length, leaf width, primary branches/plant, harvest duration, average dry fruit weight and capsaicin content besides having desirable short pedicel length and longest harvest duration. On the other hand, cluster VI revealed desirable means for early flowering and fruit harvesting, longest harvest duration and oleoresin content. Cluster II contained the 
genotypes with maximum mean values for pedicel and fruit length, plant height, average green/ red ripe fruit weight and ascorbic acid while it showed minimum mean for nonmarketable red ripe fruits per plant. Cluster I revealed maximum mean value for per cent marketable red ripe fruits/plant. In contrary, cluster IV in general, exhibited minimum/undesirable mean for majority of the traits including late flowering and first harvest and maximum non- marketable red ripe fruits/plant. It has been well established that more the genetically diverse parents used in hybridization programme, greater will be the chances of obtaining high heterotic hybrids and broad spectrum variability in segregating generations. Hence, different clusters of genotypes on the basis of means revealed divergence for different characters and can be utilized as indicators for selecting diverse parents for specific trait in hybridization programmes (Farhad 2010; Janaki et al., 2015; Bijalwan et al., 2018).

Table.1 Distribution of chilli genotypes among different clusters on the basis of Mahalanobis $\mathrm{D}^{2}$-analysis

\begin{tabular}{|l|l|l|}
\hline Clusters & $\begin{array}{l}\text { Number of } \\
\text { genotypes }\end{array}$ & Genotypes \\
\hline I & 16 & $\begin{array}{l}\text { DPCH 38-2, DPCH 38-2-2, DPCH 38-1-1, DPCH 32-1-1, DPCH } \\
\text { 57P, Surajmukhi, DPCH 26-1-1, DPCH 14-1P, DPCH 40, DPCH } \\
\text { 27, DPCH 33-1, 22 DPCH 31, 2016/ CHIVAR 6, DPCH 21, } \\
\text { 2016/ CHIVAR-5 and DPCH 13-1 }\end{array}$ \\
\hline II & 7 & $\begin{array}{l}\text { DPCH-35, DPCH 39-2, DPCH-10, DPCH-36, DPCH-17-2 } \\
\text { DPCH-41 and 2016/ CHIVAR-1 }\end{array}$ \\
\hline III & 1 & DPCH-29-1 \\
\hline IV & 6 & $\begin{array}{l}\text { 2016/ CHIVAR-4, DPCH-32-2, 2016/CHIVAR-3, DPCH 6-2, } \\
\text { DPCH-22 and DPCH-12-1 }\end{array}$ \\
\hline V & 2 & DPCH-9 and DPCH 32-2-1 \\
\hline VI & 1 & DPCH 28-1 \\
\hline
\end{tabular}

Table.2 Average intra and inter-cluster values of $D^{2}$ and $\sqrt{ } D^{2}$ among clusters

\begin{tabular}{|c|c|c|c|c|c|c|}
\hline Clusters & I & II & III & IV & V & VI \\
\hline & $\begin{array}{l}153.35 \\
(12.38)\end{array}$ & $\begin{array}{l}246.45 \\
(15.70)\end{array}$ & $\begin{array}{l}242.78 \\
(15.58)\end{array}$ & $\begin{array}{c}306.62 \\
(17.51)\end{array}$ & $\begin{array}{l}1087.81 \\
(32.98)\end{array}$ & $\begin{array}{l}996.88 \\
(31.57)\end{array}$ \\
\hline II & & $\begin{array}{l}176.83 \\
(13.30)\end{array}$ & $\begin{array}{l}438.22 \\
(20.93)\end{array}$ & $\begin{array}{l}489.68 \\
(22.13)\end{array}$ & $\begin{array}{l}1104.22 \\
(33.23)\end{array}$ & $\begin{array}{l}932.15 \\
(30.53)\end{array}$ \\
\hline III & & & $\begin{array}{c}0.00 \\
(0.00)\end{array}$ & $\begin{array}{l}263.12 \\
(16.22)\end{array}$ & $\begin{array}{l}1575.44 \\
(39.69)\end{array}$ & $\begin{array}{l}866.70 \\
(29.45)\end{array}$ \\
\hline IV & & & & $\begin{array}{l}214.93 \\
(14.66)\end{array}$ & $\begin{array}{l}1692.65 \\
(41.14)\end{array}$ & $\begin{array}{l}1005.29 \\
(31.71)\end{array}$ \\
\hline V & & & & & $\begin{array}{l}139.83 \\
\text { (11.82) }\end{array}$ & $\begin{array}{c}3462.64 \\
(58.84)\end{array}$ \\
\hline VI & & & & & & $\begin{array}{c}0.00 \\
(0.00)\end{array}$ \\
\hline
\end{tabular}

Bold values are intra-cluster distance

Data in parenthesis are $\sqrt{ } \mathrm{D}^{2}$ value 
Table.3 Cluster means for different traits of chilli genotypes distributed in six clusters

\begin{tabular}{|c|c|c|c|c|c|c|c|c|c|}
\hline Traits & I & II & III & IV & $\mathbf{V}$ & VI & Mean & Maximum & Minimum \\
\hline $\begin{array}{l}\text { Days to } \\
\text { flowering }\end{array}$ & 38.25 & $36.57 *$ & 36.67 & $39.39 * *$ & 38.33 & 36.67 & 37.65 & 39.39 & 36.57 \\
\hline $\begin{array}{l}\text { Days to first } \\
\text { harvest }\end{array}$ & 62.58 & 62.29 & 60.67 & $64.78 * *$ & 64.00 & $58.67 *$ & 62.17 & 64.78 & 58.67 \\
\hline $\begin{array}{l}\text { Pedicel length } \\
\text { (cm) }\end{array}$ & 3.1 & $3.71 * *$ & $2.79 *$ & 3.67 & 3.05 & 3.65 & 3.33 & 3.71 & 2.79 \\
\hline $\begin{array}{l}\text { Fruit length } \\
\text { (cm) }\end{array}$ & 7.09 & $8.99 * *$ & $5.41^{*}$ & 7.09 & 8.01 & 7.5 & 7.35 & 8.99 & 5.41 \\
\hline $\begin{array}{l}\text { Fruit girth } \\
\text { (cm) }\end{array}$ & 3.5 & 3.75 & $3.99 * *$ & $3.14 *$ & 3.37 & 3.72 & 3.58 & 3.99 & 3.14 \\
\hline $\begin{array}{l}\text { Fruit width } \\
\text { (cm) }\end{array}$ & 1.03 & 1.04 & $1.10 * *$ & $0.93^{*}$ & 1.04 & 1.03 & 1.03 & 1.10 & 0.93 \\
\hline $\begin{array}{l}\text { Leaf length } \\
(\mathrm{cm})\end{array}$ & 8.16 & 8.43 & $9.17 * *$ & $7.54 *$ & 8.07 & 8.56 & 8.32 & 9.17 & 7.54 \\
\hline $\begin{array}{l}\text { Leaf width } \\
\text { (cm) }\end{array}$ & 3.67 & 3.59 & $3.97 * *$ & $3.19 *$ & 3.79 & 3.68 & 3.65 & 3.97 & 3.19 \\
\hline $\begin{array}{l}\text { Primary } \\
\text { branches/plant }\end{array}$ & 5.08 & $4.20 *$ & $6.40 * *$ & 5.19 & 4.77 & 5.73 & 5.23 & 6.40 & 4.20 \\
\hline $\begin{array}{l}\text { Secondary } \\
\text { branches/plant }\end{array}$ & 14.95 & 13.95 & $10.53^{*}$ & 14.84 & $16.13^{* *}$ & $16.13^{* *}$ & 14.42 & 16.13 & 10.53 \\
\hline $\begin{array}{l}\text { Plant height } \\
\text { (cm) }\end{array}$ & 55.41 & $69.6 * *$ & $52.27 *$ & 59.79 & 62.1 & 60.80 & 60.00 & 69.6 & 52.27 \\
\hline $\begin{array}{l}\text { Average green } \\
\text { fruit weight (g) }\end{array}$ & 2.8 & $3.37 * *$ & 2.79 & $2.52 *$ & 2.88 & 3.2 & 2.93 & 3.37 & 2.52 \\
\hline $\begin{array}{l}\text { Marketable } \\
\text { green } \\
\text { fruits/plant }\end{array}$ & 77.86 & 80.55 & 73.1 & $59.31 *$ & $118.16^{* * *}$ & 100.51 & 84.92 & 118.16 & 59.31 \\
\hline $\begin{array}{l}\text { Marketable } \\
\text { green fruit } \\
\text { yield/plant (g) }\end{array}$ & 219.08 & 271.31 & 204.25 & $151.6^{*}$ & $339.65^{* *}$ & 320.92 & 251.14 & 339.65 & 151.6 \\
\hline $\begin{array}{r}\text { Harvest } \\
\text { duration }\end{array}$ & 57.27 & 58.19 & $60.00 * *$ & 57.44 & $53.50 *$ & $60.00 * *$ & 57.73 & 60 & 53.5 \\
\hline $\begin{array}{l}\text { Average red } \\
\text { ripe fruit } \\
\text { weight }(g)\end{array}$ & 3.23 & $4.55 * *$ & 3.50 & $2.74 *$ & 3.91 & 3.76 & 3.62 & 4.55 & 2.74 \\
\hline $\begin{array}{l}\text { Marketable } \\
\text { red ripe } \\
\text { fruits/plant }\end{array}$ & 36.98 & 31.66 & $25.76^{*}$ & 27.98 & $42.47 * *$ & 38.57 & 33.90 & 42.47 & 25.76 \\
\hline $\begin{array}{l}\text { Red ripe fruit } \\
\text { yield/plant (g) }\end{array}$ & 117.33 & 139.93 & 90.00 & $74.80^{*}$ & $165.71 * *$ & 145.06 & 122.14 & 165.71 & 74.8 \\
\hline $\begin{array}{l}\text { Non- } \\
\text { marketable red } \\
\text { ripe fruit/plant }\end{array}$ & 1.39 & $1.30^{*}$ & 1.85 & $1.86^{* *}$ & 1.59 & 1.60 & 1.60 & 1.86 & 1.30 \\
\hline $\begin{array}{l}\text { Total red ripe } \\
\text { fruits/plant (g) }\end{array}$ & 38.11 & 33.76 & $27.84^{*}$ & 31.70 & $44.99 * *$ & 40.63 & 36.17 & 44.99 & 27.84 \\
\hline $\begin{array}{l}\text { Per cent } \\
\text { marketable red } \\
\text { ripe fruits/plant }\end{array}$ & $97.02 * *$ & 93.28 & 92.56 & $87.08^{*}$ & 94.42 & 94.94 & 93.22 & 97.02 & 87.08 \\
\hline $\begin{array}{l}\text { Average dry } \\
\text { fruit weight (g) }\end{array}$ & 0.50 & 0.66 & $0.69 * *$ & 0.54 & 0.67 & $0.39 *$ & 0.58 & 0.69 & 0.39 \\
\hline $\begin{array}{l}\text { Dry fruit } \\
\text { yield/plant (g) }\end{array}$ & 16.61 & 18.91 & 16.67 & $14.20 *$ & $27.86^{* *}$ & 16.94 & 18.53 & 27.86 & 14.20 \\
\hline $\begin{array}{l}\text { Ascorbic acid } \\
(\mathrm{mg} / \mathbf{1 0 0 g})\end{array}$ & 55.50 & $56.25 * *$ & 52.46 & $43.62 *$ & 54.45 & 48.55 & 51.81 & 56.25 & 43.62 \\
\hline $\begin{array}{l}\text { Capsaicin } \\
\text { content }(\%)\end{array}$ & 1.85 & 1.88 & $2.57 * *$ & $1.62 *$ & 2.2 & 1.92 & 2.01 & 2.57 & 1.62 \\
\hline $\begin{array}{l}\text { Oleoresin } \\
\text { content (ASTA } \\
\text { units) }\end{array}$ & 52.69 & 48.97 & 75.17 & 59.66 & $39.09^{*}$ & $76.26^{* *}$ & 58.64 & 76.26 & 39.09 \\
\hline
\end{tabular}


Table.4 Relative contribution (\%) of individual trait to the genetic divergence among chilli genotypes

\begin{tabular}{|c|c|c|}
\hline Source & Contribution $\%$ & Times Ranked $1^{\mathrm{st}}$ \\
\hline 1 Days to flowering & $0.00 \%$ & 0 \\
\hline 2 Days to first harvest & $0.00 \%$ & 0 \\
\hline 3 Pedicel length (cm) & $0.00 \%$ & 0 \\
\hline 4 Fruit length $(\mathrm{cm})$ & $0.95 \%$ & 5 \\
\hline 5 Fruit girth $(\mathrm{cm})$ & $0.00 \%$ & 0 \\
\hline 6 Fruit width (cm) & $0.00 \%$ & 0 \\
\hline 7 Leaf length (cm) & $8.33 \%$ & 44 \\
\hline 8 Leaf width $(\mathrm{cm})$ & $0.38 \%$ & 2 \\
\hline 9 Primary branches/plant & $0.00 \%$ & 0 \\
\hline 10 Secondary branches/plant & $0.00 \%$ & 0 \\
\hline 11 Plant height (cm) & $0.57 \%$ & 3 \\
\hline 12 Average green fruit weight (g) & $0.00 \%$ & 0 \\
\hline 13 Marketable green fruits/plant & $6.82 \%$ & 36 \\
\hline 14 Marketable green fruit yield/plant (g) & $0.00 \%$ & 0 \\
\hline 15 Harvest duration & $0.00 \%$ & 0 \\
\hline 16 Average red ripe fruit weight (g) & $10.80 \%$ & 57 \\
\hline 17 Marketable red ripe fruits/plant & $17.42 \%$ & 92 \\
\hline 18 Red ripe fruit yield/plant $(\mathrm{g})$ & $0.57 \%$ & 3 \\
\hline 19 Non-marketable red ripe fruit/plant & $0.19 \%$ & 1 \\
\hline 20 Total red ripe fruits/plant $(\mathrm{g})$ & $18.56 \%$ & 98 \\
\hline $\begin{array}{l}21 \text { Per cent marketable red ripe } \\
\text { fruits/plant }\end{array}$ & $0.57 \%$ & 3 \\
\hline 22 Average dry fruit weight (g) & $2.27 \%$ & 12 \\
\hline 23 Dry fruit yield/plant (g) & $0.95 \%$ & 5 \\
\hline 24 Ascorbic acid (mg/100g) & $7.95 \%$ & 42 \\
\hline 25 Capsaicin content $(\%)$ & $5.87 \%$ & 31 \\
\hline 26 Oleoresin content (ASTA units) & $17.80 \%$ & 94 \\
\hline
\end{tabular}


Fig.1 Dendrogram showing grouping of thirty three chilli genotypes based on $\mathrm{D}^{2}$ statistics using Tocher's method



It is worth mentioning that in calculating cluster mean, the superiority of a particular genotype with respect to a given character could get diluted by other genotypes that are grouped in the same cluster but are inferior or intermediate for the character in question. Hence, apart from selecting genotypes from the clusters which have higher inter-cluster distance for hybridization, one can also think of selecting parents based on the extent of divergence with respect to a character of interest. The relative per cent contribution of individual trait to the genetic divergence among chilli genotypes was presented in Table 4. The maximum contribution towards the genetic divergence was exhibited by total red ripe fruits/ plant (18.56\%) followed by oleoresin content $(17.80 \%)$, marketable red 
ripe fruits/plant $(17.42 \%)$, average red ripe fruit weight (10.80\%), leaf length (8.33\%), ascorbic acid (7.95\%), marketable green fruits/plant $(6.82 \%)$, capsaicin content $(5.87 \%)$ and average dry fruit weight $(2.27 \%)$. The remaining traits contributed with nil to very low to the total divergence among chilli genotypes.

Selection of genotypes as superior and diverse parents for hybridization programme should be based on diverse clusters. Accordingly, best performing genotypes viz., 'DPCH-9'and 'DPCH-32-2-1' from cluster V, 'DPCH-40', DPCH-21', 'DPCH-31', 'DPCH-38-1-1', 'DPCH-38-2' and 'DPCH-27' from cluster I, 'DPCH-35', 'DPCH-39-2', 'DPCH-36' and 'DPCH-17-2' from cluster II, 'DPCH-28-1' from cluster VI and 'DPCH-29-1' from cluster III offer promise for their direct use as varieties and as potential parents in future breeding programmes to isolate transgressive segregants. The genetically divergent genotypes may be used as mapping populations to detect diversity at molecular level and also to identify molecular markers linked to desirable traits for marker assisted selection (MAS).

\section{References}

Bijalwan, P., Singh, M. and Naidu, M. 2018. Assessment of genetic divergence in chilli (Capsicum annuum L.) genotypes. Int. J. Curr. Microbiol. App. Sci., 7: 2319-7706.

Ceolin, A.C.G., Vidigal, M.C.G., Filho, P.S.V., Kvitschal, M.V., Gonela, A. and Scapim, C.A. 2007. Genetic divergence of the common bean (Phaseolus vulgaris L.) group Carioca using morpho-agronomic traits by multivariate analysis. Heriditas, 144: $1-9$.

Datta, S. and Jana, J.C. 2010. Genetic variability, heritability and correlation in chilli genotypes under Terai zone of West Bengal. SAARC J. Agric., 8: 33-45.

Dutonde, S.N., Bhalekar, M.N., Patil, B.T., Kshirsagar, D.B. and Dhumal, S.S. 2008. Genetic diversity in chilli (Capsicum annuum L.). Agric. Sci. Digest, 28: 45-47.

Eivazi, A.R., Naghavi, M.R., Hajheidari, M., Pirseyedi, S.M., Ghaffari, M.R., Mohammadi, S.A., Majidi, I., Salekdeh, G.H. and Mardi, M. 2007. Assessing wheat (Triticum aestivum L.) genetic diversity using quality traits, amplified fragment length polymorphisms, simple sequence repeats and proteome analysis. Ann. Appl. Biol., 152: 81-91.

Farhad, M., Hasanuzzaman, M., Biswas, B.K., Arifuzzaman, M. and Islam, M.M. 2010. Genetic divergence in chilli (Capsicum annuum L.). Bangladesh J. Sci. Res., 3: 1045-1051.

Janaki, M., Naidu, L.N., Venkataraman, C. and Rao, M.P. 2015. Assessment of genetic variability, heritability and genetic advance for quantitative traits in chilli (Capsicum annuum L). The Bioscan, 10: 729-733.

Khodadadi, M., Hossein, F.M. and Miransari, M. 2011. Genetic diversity of wheat (Triticum aestivum L.) genotypes based on cluster and principal component analyses for breeding strategies. Aust. J. Crop Sci., 5: 17-24.

Mishra. A., Sahu, G.S. and Mishra, P.K. 2001. Variability in fruit characters of chilli (Capsicum annuum L.). Orissa J. Hortic., 29: 107-109.

Pujar, U.U., Shantappa, T., Jagadeesha, R.C., Gasti, V.D. and Sandhyarani, N. 2017. Analysis of genetic divergence in chilli (Capsicum annuum L.) genotypes. Int. J.Pure Appl. Biosci., 5: 503-508.

Rao, C.R. 1952. Advanced Statistical 
Methods in Biometrical Research. John Wiley and Sons Inc. New York Edinburgh.

Singh, P., Jain, P.K. and Sharma, A. 2017. Genetic variability, heritability and genetic advance in chilli (Capsicum aпnиит L.) genotypes. Int. J. Curr. Microbiol. App. Sci., 6: 2704-2709.

Srinivas, B., Thomas, B. and Sreenivas, G. 2013. Genetic divergence for yield and its components traits in chilli (Capsicum frutesence L.). Int. J. Sci. Res.
Sumathy, K.M.A. and Mathew, A.G. 1984. Chilli processing. Indian Cocoa, Arecanut and Spices J., 7: 112-113.

Tomooka, N.1991.Genetic diversity and landraces differentiation of mungbean (Vigna radiate L.) Wilczek and evaluation of its wild relatives (The subgenus Ceratotropics) as breeding materials. Tech. Bull. Trop. Res. Centre, Japan No. 28. Ministry of Agriculture, Forestry and Fisheries. Japan. P.1.

\section{How to cite this article:}

Paramjeet Singh Negi and Akhilesh Sharma. 2019. Genetic Diversity of Chilli (Capsicum annuиm L.) Genotypes. Int.J.Curr.Microbiol.App.Sci. 8(04): 1820-1828.

doi: https://doi.org/10.20546/ijcmas.2019.804.211 